\title{
A Study on the Effect of Detergent Tide on the Biochemical Constituents of the Fresh Water Fish, Cirrhinus Mrigala
}

\author{
J.Vasanthi $^{1}$, S.Binukumari ${ }^{2}$ and N.Saradhamani ${ }^{3}$ \\ ${ }^{123} P G$ and Research Department of Zoology, Kongunadu Arts and Science college, Coimbatore- \\ 29, Tamilnadu,India
}

\begin{abstract}
To get an idea about the nature of the toxic effect of detergent Tide on the biochemical characteristics like total protein, carbohydrate, cholesterol of aquatic organisms. Fishes belonging to the species Cirrhinus mrigala were exposed to sublethal concentration of $3.6 \mathrm{mg}$ for 24,48 and 72 hrs respectively. The results of the present study showed a significant decrease in protein,carbohydrate,cholesterol content in the tissues studied. The kidney showed the highest percent decrease (77.27\%) in carbohydrate, (76.42\%) in protein, (80.03\%) in cholesterol content.
\end{abstract}

Keywords:Carbohydrate, Cholesterol,Cirrhinus mrigala,Detergent,Protein.

\section{Introduction}

The increase in population and rapid phase of industrialization in india has created problems of disposal of waste products.Domestic wastes and industrial effluents are being indiscriminately discharged into nearby rivers, lakes and ponds, even on the adjoining fields without any proper treatment. The presence of detergent in water accelerates the corrosive action, empedes the filtering, sedimentation and coagulation processes, increases the saturation of water with oxygen and also deteriorates the taste properties of water ([1]).Environment stress invokes compensatory metabolic changes in the organs of an animal through modification of the quality and quantity of protein ([2]).

Glycogen is a major fuel for aerobic metabolism and it plays an important role in osmoregulation, through the glucose and lactic acid.Cholesterol is known to control cell permeability, hormone regulation and protection against injuries and diseases ([3]). Effects of the detergent commando on cholesterol content of the freshwater fish Labeo rohita has been studied by ([4]).The extensive use of the detergents ( the mixture of surface active substance, mineral and organic elements) have polluting the whole of the aquatic system ([5]),([6]),([7]), ([8]), ([9]).

\section{Materials And Methods}

Cirrhinus mrigala is the fresh water carp mainly found in Northern India,Punjab,West Bengal and Orissa.Major food consists of sand,mud,algae and decaying vegetations.Breeding takes place in flooded river in monsoon month ( July - September ). Growth is recorded $25 \mathrm{~cm}$ in a year. The fingerlings of the freshwater fish, Cirrhinus mrigala ranging in weight from $3 \mathrm{~g}$ to $8 \mathrm{~g}$ and measuring $4 \mathrm{~cm}$ to $8 \mathrm{~cm}$ in length) were procured from "Tamil Nadu Fisheries, Department corporation" Mettur, Salem District. The procured bulk samples of Cirrhinus mrigala were transported to the laboratory in well aerated polythene bag and acclimatized to the laboratory conditions under natural photoperiod for one week in large plastic containers at $\left(26 \pm 5{ }^{\circ} \mathrm{C}\right)$. During this period the fish were fed with mixture of oilcake and rice bran.

Appropriate narrow range of concentration 10-50 mg was used to find the median lethal concentration, using a minimum of 6 fishes, for each concentration and the mortality was recorded for every $24 \mathrm{hrs}$ upto $72 \mathrm{hrs}$. It was found as $36 \mathrm{mg}$ for $48 \mathrm{hrs}$, using probit analysis method ([10]).Three groups of fishes were exposed to $3.6 \mathrm{mg}\left(1 / 10^{\text {th }}\right.$ of $48 \mathrm{hrs}$ Lc50 value) concentration of the detergent 'Tide' for 24,48 and $72 \mathrm{hrs}$ respectively.Another group was maintained as control.At the end of the each exposure period, fishes were sacrificed and tissues such as liver, gill, muscle and kidney were dissected and removed,The tissues $(10 \mathrm{mg})$ were homogenized in $80 \%$ methanol,centrifuged at $3500 \mathrm{rpm}$ for 15 minutes and the clear supernatant was used for the analysis of different parameters.

Total protein concentration was estimated by the method of ([11]).Quantitative estimation of carbohydrate in the tissues was done following the method described by ([12]). Cholesterol was estimated based on enzymatic method using cholesterol esterase,cholesterol oxidase and peroxidise ([13]).

\section{Results And Discussion}

In the present investigation, the effect of an detergent Tide on biochemical nature of carbohydrate, protein, cholesterol in Blood and different tissues (liver,muscle,kidney,gills,brain) of the freshwater fish,Cirrhinus mrigala have been studied and presented as figures(1-6).The results were statistically analysed. 
IV. FIGURES

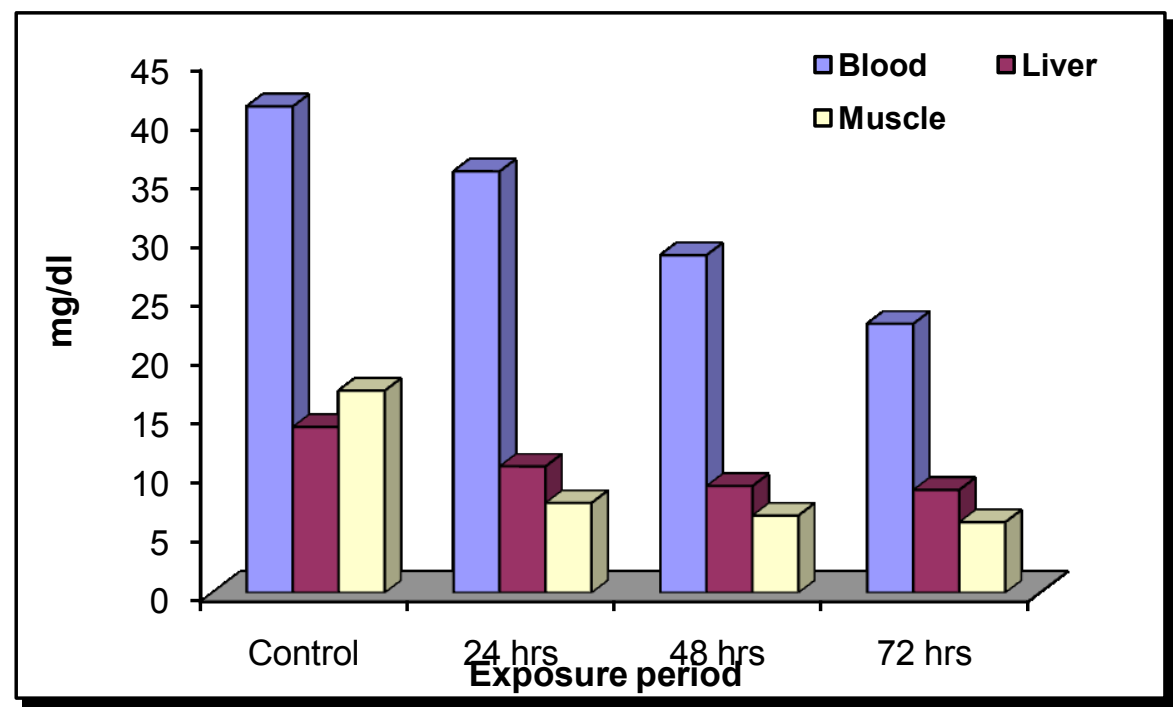

Figure 1: Levels of carbohydrate ( $\mathrm{mg} / \mathrm{dl})$ in different tissues (Blood, liver \& muscle) of the fish Cirrhinus mrigala on exposed to the detergent Tide $(3.6 \mathrm{mg} / \mathrm{L})$

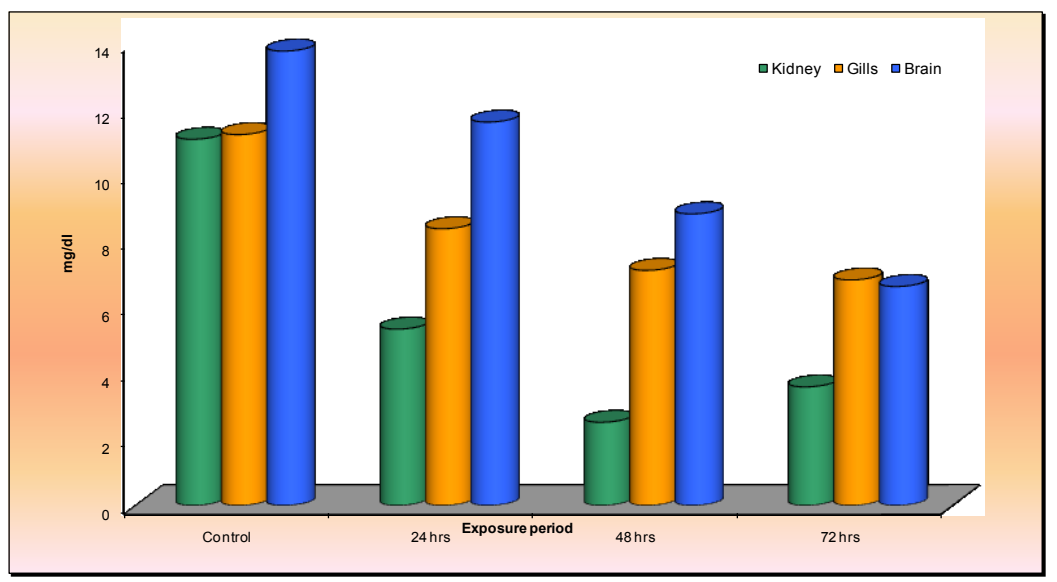

Figure 2: Levels of carbohydrate (mg/dl) in different tissues (Kidney, Gills, Brain) of the fish Cirrhinus mrigala on exposed to the detergent Tide $(3.6 \mathrm{mg} / \mathrm{L})$

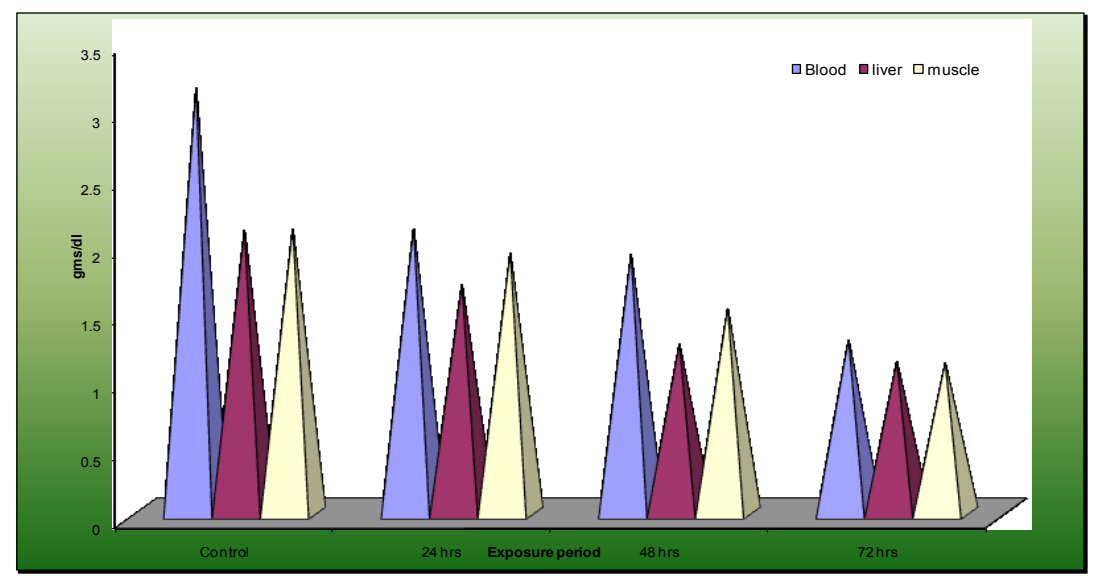

Figure 3: Levels of protein (gms/dl) in different tissues (Blood, liver \& muscle) of the fish Cirrhinus mrigala on exposed to the detergent Tide $(3.6 \mathrm{mg} / \mathrm{L})$ 


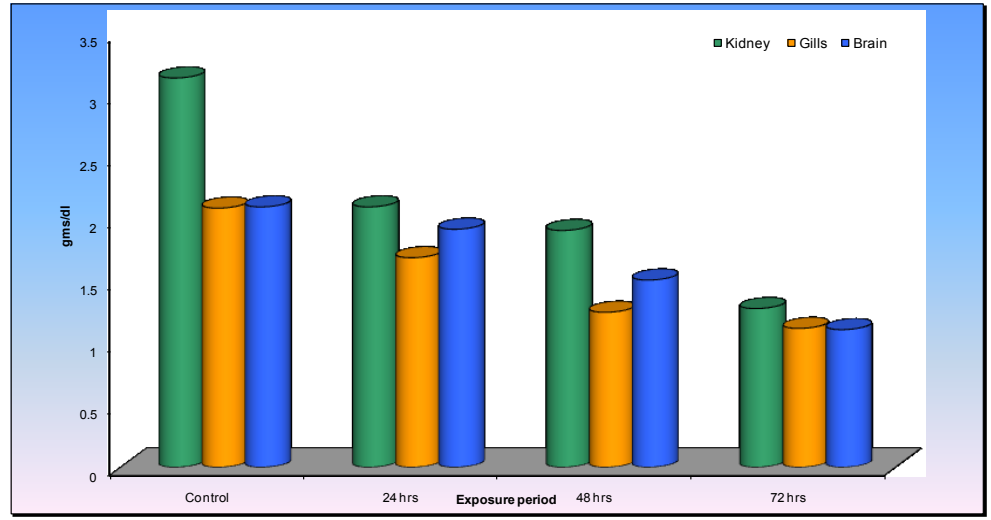

Figure 4: Levels of protein (gms/dl) in different tissues (Kidney, Gills, Brain) of the fish Cirrhinus mrigala on exposed to the detergent Tide $(3.6 \mathrm{mg} / \mathrm{L})$

The control value of carbohydrate in Blood,liver,muscle,kidney,gills and brain was found to be $41.20 \mathrm{mg} / \mathrm{dl}, 14.05 \mathrm{mg} / \mathrm{dl}, 17.12 \mathrm{mg} / \mathrm{dl}, 11.09 \mathrm{mg} / \mathrm{dl}, 11.23 \mathrm{mg} / \mathrm{dl}$ and $13.76 \mathrm{mg} / \mathrm{dl}$ in $36 \mathrm{mg}$ concentration of Tide respectively.The carbohydrate level was found to be $35.70,28.60$ and $22.79 \mathrm{mg} / \mathrm{dl}$ in 24,48 and 72 hours respectively in Blood, $10.71,9.04$ and $8.71 \mathrm{mg} / \mathrm{dl}$ in 24,48 and 72 hours respectively in liver, $7.61,6.54$ and $5.98 \mathrm{mg} / \mathrm{dl}$ in 24,48 and 72 hours respectively in muscle, $5.34,2.52$ and $3.59 \mathrm{mg} / \mathrm{dl}$ in 24,48 and 72 hours respectively in kidney,8.38, 7.12 and $6.83 \mathrm{mg} / \mathrm{dl}$ respectively in 24,48 and 72 hours in Gills, $11.61,8.83$ and $6.63 \mathrm{mg} / \mathrm{dl}$ in 24,48 and 72 hours respectively in Brain.("Fig"1\&2). The decrease in the glycogen content might have been due to the possible onset of glycogenolysis forming free glucose in the exposed tissue ([14]).Decreased glycogen synthesis is also attributed to the inhibition of the enzyme glycogen synthatase which mediates glycogen synthesis([15]).

The control value of protein in Blood,liver,muscle,kidney,gills and brain was found to $3.14 \mathrm{mg} / \mathrm{dl}$, $2.09 \mathrm{mg} / \mathrm{dl}, 2.10 \mathrm{mg} / \mathrm{dl}, 1.40 \mathrm{mg} / \mathrm{dl}, 1.09 \mathrm{mg} / \mathrm{dl}$ and $1.91 \mathrm{mg} / \mathrm{dl}$ in $36 \mathrm{mg}$ concenteration of Tide respectively.The protein level was found to be $2.10,1.91$ and $1.28 \mathrm{mg} / \mathrm{dl}$ in 24,48 and 72 hours respectively in Blood, $1.69,1.25$ and $1.12 \mathrm{mg} / \mathrm{dl}$ in 24,48 and 72 hours respectively in liver, $1.92,1.51$ and $1.11 \mathrm{mg} / \mathrm{dl}$ in 24,48 and 72 hours respectively in muscle, $0.83,0.33$ and $0.38 \mathrm{mg} / \mathrm{dl}$ in 24,48 and 72 hours respectively in kidney, $0.47,0.41$ and $0.65 \mathrm{mg} / \mathrm{dl}$ respectively in 24,48 and 72 hours in Gills, $1.28,1.03$ and $0.55 \mathrm{mg} / \mathrm{dl}$ in 24,48 and 72 hours respectively in Brain.("Fig" $3 \& 4$ ). The decrease in the total protein observed is due to proteolysis that results in the production of free amino acids. Proteins are also used in TCA cycle for energy production in stress condition ([16]).The decreased trend of the protein content in most of the tissues may be due to metabolic utilization of the ketoacids to gluconeogenesis pathway for the synthesis of glucose([15]).

The control value of cholesterol in Blood,liver,muscle,kidney,gills and brain was found to $51.50 \mathrm{mg} / \mathrm{dl}$, $12.02 \mathrm{mg} / \mathrm{dl}, 16.21 \mathrm{mg} / \mathrm{dl}, 10.12 \mathrm{mg} / \mathrm{dl}, 9.16 \mathrm{mg} / \mathrm{dl}$ and $15.21 \mathrm{mg} / \mathrm{dl}$ in $36 \mathrm{mg}$ concenteration of Tide respectively. The protein level was found to be $39.61 \mathrm{mg} / \mathrm{dl}, 30.23 \mathrm{mg} / \mathrm{dl}$ and $26.35 \mathrm{mg} / \mathrm{dl}$ in 24,48 and 72 hours respectively in Blood, $10.02 \mathrm{mg} / \mathrm{dl}, 9.19 \mathrm{mg} / \mathrm{dl}$ and $8.16 \mathrm{mg} / \mathrm{dl}$ in 24,48 and 72 hours respectively in liver, $9.15 \mathrm{mg} / \mathrm{dl}, 8.37 \mathrm{mg} / \mathrm{dland}$ $5.22 \mathrm{mg} / \mathrm{dl}$ in 24,48 and 72 hours respectively in muscle, $5.01 \mathrm{mg} / \mathrm{dl}, 4.05 \mathrm{mg} / \mathrm{dl}$ and $2.02 \mathrm{mg} / \mathrm{dl}$ in 24,48 and 72 hours respectively in kidney, $7.72 \mathrm{mg} / \mathrm{dl}, 5.22 \mathrm{mg} / \mathrm{dl}$ and $4.23 \mathrm{mg} / \mathrm{dl}$ respectively in 24,48 and 72 hours in Gills, $12.46 \mathrm{mg} / \mathrm{dl}, 10.20 \mathrm{mg} / \mathrm{dl}$ and $9.66 \mathrm{mg} / \mathrm{dl}$ in 24,48 and 72 hours respectively in Brain.("Fig"5\&6).The decrease in total lipid level may be due to utilization of lipid for energy demand under the conditions of stress ([17]). The alterations in cholesterol content may be due to its utilization in corticisteroidogenesis and also impairment in the synthesis of cholesterol.Lipids may be mobilized to meet the energy requirement of fish either through oxidation or a process of gradual instauration of lipid molecules([18])

\section{Conclusion}

Based on the result obtained in the present study,it was concluded that the biochemical alterations in different tissues may lead to fish morbidity and mortality.

\section{Acknowledgements}

The authors thank the Staff members,Head of the Department of Zoology,Kongunadu Arts and Science college for providing necessary facilities to carry out the project. 


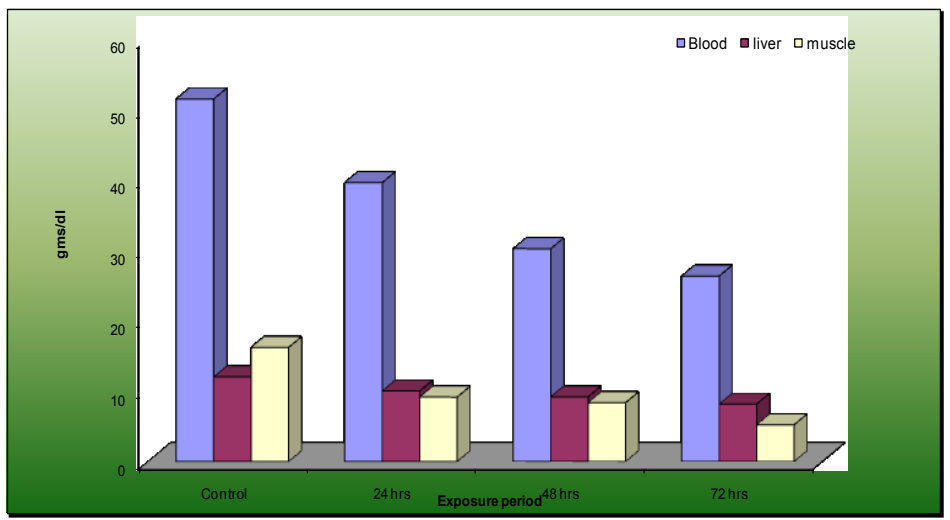

Figure 5: Levels of cholesterol (mg/dl) in different tissues (Blood, liver \& muscle) of the fish Cirrhinus mrigala on exposed to the detergent Tide $(3.6 \mathrm{mg} / \mathrm{L})$

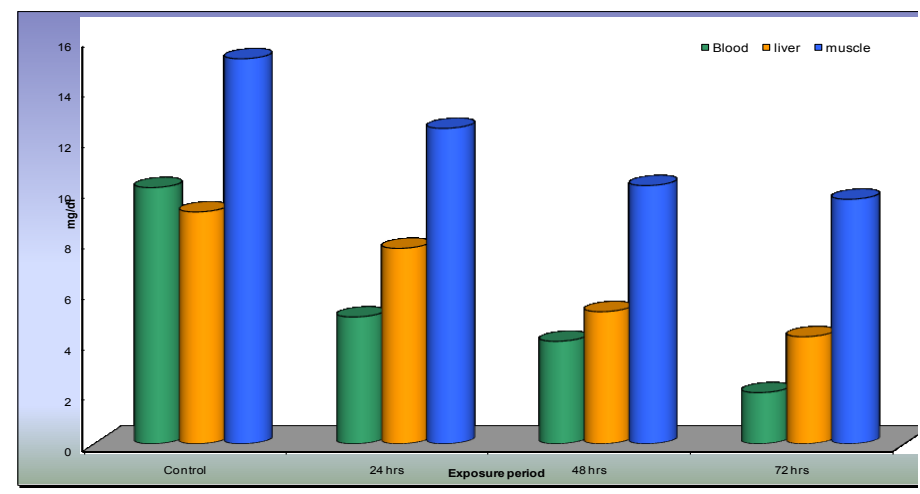

Figure 6: Levels of cholesterol (mg/dl) in different tissues (Kidney, Gills, Brain) of the fish Cirrhinus mrigala on exposed to the detergent Tide $(3.6 \mathrm{mg} / \mathrm{L})$

\section{References}

[1] A.Chojnacki,Zanieczyszczenie wod powierzchniowych przez detergency.Gospodarka wodna,1,1970,14-16.

[2] A.L.Lehninger,In:Biochemistry,New York,1970,pp.313-314.

[3] E.S.West,W.R. Todd,H.S. Mason,and J.J.V. Bruggen,'”Textbook of Biochemistry $4^{\text {th }}$ edition.Oxford and IBH publishing Co.,New Delhi,India".1974, pp.1595.

[4] N.Saradhamani,R. Saraswathi and B. Dhanalakshmi ,Effects of the detergent commando on cholesterol content of freshwater fish Labeo rohita, 2007.

[5] S.Eddy,T.Fumio,S.C.Augusto ,Toxicity of linear alkyl benzene sulphonate(LAS) to Juvenile Kuruma shrimp,J.Tok.Univ.Fish, 85,1998,1-100.

[6] Leela Siva Parvathi,M.D.Chandra Sekhara Reddy and A.Nadamunichetty,In vivo recovery and long term effect of phosalone on total lipid and triglycerides in fresh water fish Tilapia mossambica(peters),Poll.Res,19(3),2000,345-351.

[7] R.Sornaraj,A.J.A.Ranjith Singh,and A. Pushparaj, Alterations in the protein metabolism of the fish Mystus vittatus exposed to pesticidal stress under laboratory conditions, Poll.Res,26,2007,107-112.

[8] S.Afaq and K.S.Rana, Impact of leather dyes on total protein of fresh water teleost,Cirrhinus mrigala(Ham).Asian J.Exp.Sci, Bangalore university,India,23(1),2009,299-302.

[9] V.Sreenivasa and R. Indirani, Impact of Dimethoate on biochemical constituents in the fish,Oreochromis mossambicus,J.Ecotoxicol.Environ.Monit, 20(2),2010,151-156.

[10] D.J.Finney, Probit analysis, $3^{\text {rd }}$ edition,(London:Cambridge University press), 1971,pg.20.

[11] O.H.Lowry,N.J.Rose Brough,A.L.Farr and R.J.Randall, Protein measurements with the folin phenol reagent,J.Biol.Chem,193,1951,265-275.

[12] J.E.Hedge's,and B.T. Hofreiter, In: Carbohydrate chemistry 17(Eds Whistler,R.L and Be Miller,J.N).Academic press New York, 1962.

[13] W.Richmond, Preparation and properties of a cholesterol oxidase from Nocardia sp and its application to the enzymatic assay of total cholesterol in serum.Clin.Chem.19,1973,1350-1356.

[14] V.Sreenivasa, Studies on the effect of pesticide on cardiac and body muscles of freshwater gobiid fish Glossogobius giuris (Ham).Ph.D. thesis, 2002.

[15] K.Veeriah,P.Srinivas Rao,A.Symyuktha Rani and H. Dhilleswarao, Changes in Biochemical parameters of Fresh water fish Labeo rohita exposed to Lethal and Sub-lethal concentrations of Indoxacarb,Int.J.Bioassays, 02(10),2013,1382-1387.

[16] P.Baskaran,G.Gopalakrishnasamy and Sathiyabama, Impact of commercial detergent (Nirma) on feeding energetic and protein metabolism in the fresh water teleost fish Oreochromis mossambicus.J.Ecotoxicol.Environ.Monit.1(1),1991,31-40.

[17] A.Horport,V.M.Roewell and A. Mayer, A review of physiological chemistry, $16^{\text {th }}$ edition.Lange.Medical Publication,California, 1977, pp.269.

[18] D.Shelke Abay, Comparative study of cholesterol Alterations in a Fresh water teleost fish,Amblypharyngodon Mola exposure to Heavy metals, The Bioscan,J.of Life Sciences 8(3),2013,1001-1004. 